\title{
Understanding the Number Concepts through Learning Connected Mathematics (CM): A Local Cultural Approach
}

\author{
Desi Andriani ${ }^{1}$, Wahyu Widada ${ }^{1, *}$, Dewi Herawaty ${ }^{1}$, Hafizatul Ardy ${ }^{1}$, Khathibul Umam Zaid Nugroho ${ }^{1}$, \\ Nilna Ma'rifah ${ }^{1}$, Dessy Anggreni ${ }^{2}$, Abdurrobbil Falaq Dwi Anggoro ${ }^{1}$ \\ ${ }^{1}$ Department of Mathematics Education, Universitas Bengkulu, Indonesia \\ ${ }^{2}$ SMP N 16 Kota Bengkulu, Bengkulu, Indonesia
}

Received October 29, 2019; Revised January 21, 2020; Accepted February 7, 2020

Copyright $\odot 2020$ by authors, all rights reserved. Authors agree that this article remains permanently open access under the terms of the Creative Commons Attribution License 4.0 International License

\begin{abstract}
Mathematics becomes an important subject in elementary school. Numbers are one part of school mathematics. Learning that links between concepts and what is close to students' minds makes it easy for students in the process of reaching concepts. This is CM based on local culture. This research used a $2 \times 2$ factorial design. The population is all elementary school students from the "Integrated Islamic Foundation" in Bengkulu City. Samples were taken by using an intact group technique. The total sample is 60 students. With the local culture-based CM learning for experimental class and conventional learning for control class, the research instrument is a test of the ability to understand the concept of numbers. It is a valid and reliable instrument. The data was analyzed using the ANCOVA statistical test. The results of this study are Fo $(A)=9.7289$ with, $\mathrm{df}=(1,57)$ and $\mathrm{p}$-value $=0.090<0.05$, which means Ho is rejected. It is showed that there is a linear effect of the covariate (initial ability) to understand the concept between the students who follow the learning by using $\mathrm{CM}$ with a local cultural approach. Fo $(B)=4.8096$, df $(1,57)$ and $\mathrm{p}$-value $=0.016<0.05$. In this case, Ho was also rejected. Thus, it can be inferred that there is the influence of CM learning with a local cultural approach on the ability to understand number concepts. It can be concluded that the average score and comprehension of the number concept for students who were taught by using CM learning was higher than the students who were taught with conventional learning models. Finally, the mean score for students' ability to understand the number concepts among the students who were given local culture-based materials was higher than the students who were given the materials which are not based on local culture.
\end{abstract}

Keywords connected Mathematics, Local Culture,
Concept Understanding

\section{Introduction}

Mathematics is the main subject of elementary school students. This is often the main reason why they are learning mathematics and feel anxiety with the mathematical concept [1]. Mathematics lessons become the most difficult material to be understood by the students. The effect is that the students are afraid to learn mathematics at schools. Probably, the process of learning was boring, and also the teachers who taught mathematics can not design the learning well. Also, mathematics is taught structurally and mechanically. As a result, students fail to understand the concepts in mathematics correctly. Therefore, mathematics learning is needed to be connected with daily life. So, the teachers need to develop an empirical mathematics learning [2]. This is connected to mathematics [3], which is the development of connected mathematical material. In Connected Mathematics (CM), the word connected has three meanings. There is a context that is connected to the environment where the students live [4]. It is also called a local culture [5][6]. There are thematic ideas in mathematics that connect the units and strands, together with symbiotically linking at the unit and grade level. Everything becomes coherent. It was called a Connected Mathematics Project (CMP) [3]. In learning, mathematics will be more meaningful if it connects with the local culture [7].

The local culture is one of the ways that make students easier to begin to learn mathematics. It is often called 
ethnomathematics [8]. By starting-point problems that are close to the students' culture, they can easily reach the mathematical concepts, e.g. elementary school students in which they can easily understand the concepts and properties of numbers through CM [3]. The mathematical practices are presented in student-friendly languages. CM included in each unit that is called Mathematical Practice and Thinking Habits. The students are included in Mathematical Reflection, with a more open approach to mathematical problems facing them[4]. It is a learning approach that starts with a realistic mathematical problem. The students who use realistic mathematics learning tools can understand better than the students who study by using the conventional method about the concept of numbers higher [9].

In learning $\mathrm{CM}$, the teacher uses problems to assess the students' thinking. It is done during exploring and summarizing the learning phases [4]. CM has more problems that required students to choose the appropriate operation, function, or form to solve the problem. Also, there are more students' meta-cognition questions [10][11]. Good problems in CM are carefully ordered to achieve the goals of learning mathematics.

Mathematics at school emphasizes on students' understanding facts, concepts, principles, and operations [12]. It is an effort to learn students meaningfully. According to an expert, understanding mathematical concepts is the result of the construction or reconstruction of mathematical objects. In learning connected mathematics, students can build relationships between actions, processes, objects, and other schemes. It can build a mature scheme. This scheme is useful in the problem-solving process. Besides, it can be used as a catalyst in determining connectivity among mathematical objects [13][14]. Therefore, learning mathematics through $\mathrm{CM}$ enhances the interconnection process in students' information processing systems.

$\mathrm{CM}$ is an inquiry-based mathematics learning approach. Mathematical concepts and principles are very meaningful for students [3]. It is a series of assignments that are sequentially explored and explored in depth by students. $\mathrm{CM}$ helps the students develop a comprehensive understanding of mathematical concepts. In this case, the students focus on problem-solving strategies, communicate their reasons, offer evidence, and use representations [15].

The results of the internal formative evaluation that has been conducted on the Connected Mathematics Project (CMP), found that CMP schools were significantly superior to non-CMP schools. Through CMP, it can be trusted that the program helps students become better problem solvers [16]. CM is even more meaningful if the starting point of learning is based on the local culture. Then, mathematics is a cultural product which means that culture with all its complexity and contestation is an important aspect of mathematics education [14].
Therefore, learning mathematics with a CM approach and based on local culture is a very meaningful learning strategy. That is more realistic learning of mathematics. In ethnomathematics-based mathematics learning, the students' mathematical communication skills are taught with a realistic learning approach higher than those with traditional learning approaches [17]. That also happens for mathematical problem-solving skills [18]. Ethnomathematics is playing a very good role as an approach in learning mathematics [5] [19][20].

Action research shows that the exploration of functional relationships and spatial concepts in everyday language using the context of children's experiences is important in mathematics education [21]. Therefore, mathematics has a broader meaning that is something meaningful about mathematical knowledge, mathematical skills and ways of thinking mathematics. It also means that mathematics develops in state embryos involving cultural diversity [22]. The approach in learning CM based on local culture is an approach to learn mathematics that gives students the broadest opportunity to build their mathematical knowledge with a local cultural starting point. It aims at helping students and teachers develop mathematical knowledge, understanding, and skills while also awareness and appreciation of the enrichment of the relationship between the parts of mathematics and between mathematics with other subjects. CM emphasizes the ability to use mathematical tools, resources, procedures, knowledge, and ways of thinking to make understanding of new situations [23]. The students build a mature scheme that is a student-built bridge for students from real situations or concrete situations to formal mathematics. The students make their models in solving the problems. The model is carried out through a process of abstraction, idealization, and generalization of situations close to students' minds. The students make generalizations and formalizations based on special circumstances of solving contextual problems. Thus, we believe to implement $\mathrm{CM}$ based on local culture for mathematics learning at school. So, we want to answer the question 'how the ability to understand the concept of numbers through learning connected mathematics with a local cultural approach?'

\section{Methods}

The type of research conducted in this study was quasi-experimental research. The place of this research was the "Integrated Islamic" Elementary School in Bengkulu City. The research time was planned for 5 months that begin from the planning until the reporting process, from January 2019 up to May 2019. The population in this study were all elementary school students from the Integrated Islamic Foundation "Al-Fida" in Bengkulu City. The sample of 60 students in this study 
was taken by using the intact group technique with the local culture-based CM learning for experimental class and conventional learning for control class. The dependent variable is the ability to understand mathematical concepts. The covariate variable of research is the students' initial ability. This research design is $2 \times 2$ factorial. See Table 1 .

Table 1. Factorial Design $2 \times 2$

\begin{tabular}{|c|c|c|}
\hline \multirow{2}{*}{$\begin{array}{c}\text { Learning } \\
\text { Approach }\end{array}$} & \multicolumn{2}{|c|}{ Starting-point Learning } \\
\cline { 2 - 3 } & $\begin{array}{c}\text { Local Culture } \\
(\mathrm{E})\end{array}$ & $\begin{array}{c}\text { Without Local Culture } \\
(\mathrm{NE})\end{array}$ \\
\hline $\mathrm{CM}(\mathrm{T})$ & $(\mathrm{T}, \mathrm{E})$ & $(\mathrm{T}, \mathrm{NE})$ \\
\hline Conventional $(\mathrm{K})$ & $(\mathrm{K}, \mathrm{E})$ & $(\mathrm{K}, \mathrm{NE})$ \\
\hline
\end{tabular}

Table 1 shows that the treatment factors are the learning approach and the starting point of the learning. The learning approach factor consists of CM (denoted by $T$ ) and Conventional (symbolized $K$ ). The starting point factors for learning consist of local culture (denoted by $E$ ) and without local culture (denoted by $N E$ ).

The instrument of this study was the test for understanding the number concepts. That is to know and measure the level of ability to understand students' mathematical concepts before and after learning. There are seven indicators used to determine the ability to understand the concept of numbers. These are (1) defining the concept of numbers verbally and in writing, (2) identifying and making examples and not examples, (3) Using models, diagrams and symbols to represent a concept, (4) Changing a form of representation to another form, (5) Identifying various meanings and interpretations of concepts, (6) Identifying the characteristics of a concept and recognizing the conditions that determine a concept, and (7) Comparing and differentiating concepts.

The instrument was standardly based on panelist tests and empirical tests. The test had a high level of confidence based on the reliability index that was 0.873 . Each item was valid, with a validity level which was more than 0.65 .

Before giving the treatment to the control or experimental class, a pre-test was given by using a test sheet of ability to understand the concepts. After that, in the experimental class, the learning was done by using a realistic learning model based on local culture, realistic mathematics learning was not based on local culture, conventional learning based on local culture. While in the control class, the learning had been done by using conventional learning which was not based on local culture. After giving different treatment for the four classes, then the post-test was given by using a test sheet to understand the students' mathematical concepts. Based on the results of the post-test, the final research data was obtained.

Data collection techniques used in the study were tests of students' understanding of mathematical concepts before and after the treatment for both experimental class and conventional models to the control class. The test was firstly tested in the pilot project class to determine the validity, reliability, distinguishing features, and test the difficulty of the test before giving the tests to the experimental and the control class.

In quantitative research, the data was analyzed from the activity of all respondents that have been collected. The data analysis activity begins from grouping the data based on variables and types of respondents, tabulating data based on variables from all respondents, presenting data for each variable studied, calculating to answer the problem formulation and hypotheses that have been proposed.

Data analysis in this study was the result of students' tests on the understanding of mathematical concepts. In this study, the data that has been described must be tested before the prerequisites are analyzed. The prerequisite tests used in this study were data normality test and data homogeneity test. The following prerequisite tests were used in this study such as a test for normality, homogeneity, and linearity.

Hypothesis testing of this study used ANCOVA. It is an analysis that aims to reduce error variance by eliminating the influence of non-categorical variables that are believed to bias the results of the analysis. Also, the ANCOVA test is a useful analytical technique to improve the precision of an experiment because it regulates the influence of other uncontrolled independent variables. ANCOVA is used if the independent variable includes a quantitative variable. In ANCOVA used the concept of ANOVA and regression analysis.

\section{Results and Discussion}

The research data was obtained based on the ability test of understanding the concept of numbers from CM Islamic elementary school students in Bengkulu City. We provided a pre-test and post-test for both groups of students. The two groups were the experimental and control class. Pre-test data retrieval aims to determine the initial abilities of students. That is the covariate. After taking the pre-test data collection, then proceed with the treatment in the experimental class by using CM learning with a local cultural approach. However, for the control group being taught through learning takes place conventionally as is usually done by the teacher who teaches the number concept material in elementary schools and does not base local culture as a starting point. After the treatment was given, it is continued by giving a post-test to the two classes, namely the experimental class and the control class. It aims to determine the ability to understand the number of concepts of students after being given treatment.

The learning implementation process was carried out based on the lesson plan that was designed earlier by the 
researcher with CM learning of the local cultural approach for the experimental class, and conventional learning for the control class. Research data obtained in advance would be presented in descriptions form because the data obtained were raw. The data had the highest value, lowest value, mean, median, mode and standard deviation of each class for each variable. The following will describe the data obtained from the results of the pre-test and post-test problem-solving abilities and mathematical communication skills of students in the experimental and control class.

Prerequisite testing in conducting the test by using the ANCOVA test is that the data must normally be distributed and the data variance is homogeneous. Data normality test is used to determine whether the population data of the two variables is normally distributed or not. To analyze the normality test, the researchers used SPSS version 25 software. So, if the probability value $>0.05$ then the population is normally distributed. The results of the normality test can be seen in Table 2 .

Table 2. Test of Normality for Experiment Group

\begin{tabular}{|c|c|c|c|c|c|c|}
\hline \multirow[t]{2}{*}{ Group } & \multicolumn{3}{|c|}{ Kolmogorov-Smirnov ${ }^{\mathrm{a}}$} & \multicolumn{3}{|c|}{ Shapiro-Wilk } \\
\hline & Statistic & df & Sig. & Statistic & $\mathrm{df}$ & Sig. \\
\hline $\begin{array}{l}\text { Pre-Test Experiment CM- } \\
\text { Ethno }\end{array}$ & 0.151 & 29 & 0.137 & 0.879 & 29 & 0.572 \\
\hline $\begin{array}{l}\text { Post-Test Experiment CM- } \\
\text { Ethno }\end{array}$ & 0.145 & 29 & 0.103 & 0.931 & 29 & 0.653 \\
\hline
\end{tabular}

Based on Table 2, the normality test at a significant level of $5 \%$ in each sample for the group of experiments as follows: The pre-test score of understanding the mathematical concepts in the CM learning experimental group with the local cultural approach obtained the value of $p$ (sig) Kolmogorov-Smirnov $=0.137$ and $p$ (sign) Shapiro-Wilk $=0.572$. It states that a value of $p$ (sig) $>$ 0.05 then Ho is accepted, so it can be concluded that the data is taken from a normally distributed population. The post-test score of the ability to understand mathematical concepts in the CM learning experimental group with the local cultural approach obtained the value of $p$ (sig) Kolmogorov-Smirnov $=0.103$ and $\mathrm{p}$ (sig) Shapiro-Wilk $=$ 0.931 . It shows that the value of $p(\mathrm{sig})>0.05$ then Ho is accepted, so it can be concluded that the data is taken from a normally distributed population.

Testing the normality of mathematical communication ability data and the ability to understand further mathematical concepts in the control class with conventional learning using the Kolmogorov-Smirnov and Shapiro-Wilk tests as shown in Table 3.
Table 3. Normality Text for Control Group Data

\begin{tabular}{lccccccc}
\hline Group & \multicolumn{3}{c}{ Kolmogorov-Smirnov $^{\mathrm{a}}$} & \multicolumn{3}{c}{ Shapiro-Wilk } \\
& Statistic & df & Sig. & Statistic & df & Sig. \\
\hline Pre-test (Control Group) & 0.139 & 29 & 0.191 & 0.875 & 29 & 0.427 \\
& & & & & & \\
Post-test (Control Group) & 0.157 & 29 & 0.198 & 0.837 & 29 & 0.756 \\
\hline a. Lilliefors Significance Correction & & & & &
\end{tabular}

Table 3 is the normality test at a significance level of $5 \%$ in each sample for the control group. The pre-test score of the ability to understand mathematical concepts in the control group of conventional learning models obtained the value of $p$ (sign) Kolmogorov-Smirnov = 0.191 and $\mathrm{p}$ (sig) Shapiro -Wilk $=0.427$. Because the value of $p(\operatorname{sig})>0.05$ then Ho is accepted, so it can be concluded that the data is taken from a normally distributed population. Post-test scores on the ability to understand mathematical concepts in the control group of conventional learning models obtained the value of $p$ (sig) Kolmogorov-Smirnov $=0.198$ and $\mathrm{p}($ sig) Shapiro-Wilk $=$ 0.756 . Because the value of $p($ sig $)>0.05$ then Ho is accepted, so it can be concluded that the data is taken from a normally distributed population.

Next, we do a homogeneity test. It was aimed to find out whether the two classes used were homogeneous (the level of distribution of students' abilities in the two classes tested was the same). The data used are the results of the students' ability test. A homogeneity test is done to find out whether the data is homogeneous or not. Homogeneity test with Levene's test for similarity of variance as seen in Table 4.

Table 4. Levene's test of Equality of Error Variances ${ }^{\mathrm{a}}$

\begin{tabular}{cccc}
\hline $\mathrm{F}$ & $\mathrm{df1}$ & $\mathrm{df2}$ & Sig. \\
\hline 3.573 & 1 & 58 & 0.231 \\
\hline
\end{tabular}

Based on Table 4, it can be described that through the following pair of hypotheses:

- Ho: $\sigma^{2} 1=\sigma^{2} 2=\sigma^{2} 3$

- Ha: besides Ho

Table 4 shows that that $F=3,573$ with $d f(1,58)$ and $p$-value $=0.321>0.05$. It means that Ho was accepted. Thus, the average parameter of the ability to understand the concept of the two groups of sample data has the same/homogeneous variance.

We also do other prerequisite tests, namely linearity tests. That is to find out whether a variable has a linear relationship or not significantly. Linearity test results of the ability to understand mathematical concepts can be seen in Table 5. 
Table 5. Test of Between-Subjects Effects

\begin{tabular}{lrrrrr}
\hline Source & $\begin{array}{c}\text { Type III Sum } \\
\text { of Squares }\end{array}$ & \multicolumn{1}{c}{ Df } & Mean Square & \multicolumn{1}{c}{ F } & \multicolumn{1}{c}{ Sig. } \\
\cline { 1 - 5 } Corrected Model & 357,891 & 2 & 178,946 & 3.4153 & 0.027 \\
Intercept & $1,236,472$ & 1 & $1,236,472$ & 23.5990 & 0.000 \\
X & 325,671 & 1 & 325,671 & 6.2157 & 0.023 \\
B & 3,645 & 1 & 3,645 & 0.0696 & 0.875 \\
Error & $2,986,524$ & 57 & 52,395 & & \\
\hline
\end{tabular}

Based on the analysis of the data in Table 5, we can describe the regression alignment of the two treatment groups as follows.

Hypothesis Pair:

- Ho: $(A B) i j \mathrm{X}=0$

- Ha: beside Ho

Table 5 shows that $\mathrm{F}=0.0696$ with $d f(1,75)$ and $p$-value $=0.875>0.05$ which means Ho is accepted. It can be concluded that the regression coefficients of the two groups are homogeneous. It can be said that the two regression equations are parallel.

Based on the prerequisite test, the scoring ability of the concept of comprehension of numbers is homogeneous data, and the regression equations of the two sample groups are parallel. Therefore, the analysis of covariance data on the ability to understand mathematical concepts can be continued.

Next, we do a hypothesis test. Based on the score data of the ability to understand the concept of numbers, the test with covariance analysis is presented in Table 6 .

Table 6. Test of Test of Between-Subjects Effects

\begin{tabular}{lrrrrr}
\hline Source & $\begin{array}{c}\text { Type III Sum } \\
\text { of Squares }\end{array}$ & Df & Mean Square & \multicolumn{1}{c}{ F } & Sig. \\
\hline Corrected & 1327 & 2 & 663.50 & 9.5167 & 0.000 \\
Model & 9265 & 1 & 9.265 .00 & 132.8900 & 0.000 \\
Intercept & 678.29 & 1 & 678.29 & 9.7289 & 0.090 \\
A & 335.32 & 1 & 335.32 & 4.8096 & 0.016 \\
B & 3974 & 57 & 69.72 & & \\
Error & & & & & \\
\hline
\end{tabular}

Based on Table 6, it can be described as follows. Fo (A) $=9.7289$ with $d f=(1,57)$ and $p$-value $=0.090<0.05$, which means Ho is rejected. We can conclude that there is a linear effect of the covariate (initial ability) on the ability of students to understand the concept of learning in $\mathrm{CM}$ learning with a local cultural approach. Fo (B) = 4.8096, $d f(1,57)$ and $p$-value $=0.016<0.05$. That also Ho was rejected. Thus there is the influence of CM learning with a local cultural approach to the ability to understand number concepts.

To determine the difference in influence between the two approaches, further testing is carried out as follows. See Table 7.
Table 7. Parameter Estimates

\begin{tabular}{lcccc}
\hline Parameter & B & $\begin{array}{c}\text { Std. } \\
\text { Error }\end{array}$ & t & Sig. \\
\hline Intercept & 39,765 & 4,126 & 9.638 & 0.000 \\
{$[\mathrm{~A}=1.00]$} & 17,865 & 2,147 & 8.321 & 0.000 \\
\hline
\end{tabular}

Based on Table 7, the t-test with $t=8,321$ and $p$-value $=0.00<0.05$ which means that Ho is rejected. Thus the average score of number concept understanding ability for students who was taught with high CM learning higher than the students who was taught with conventional learning models after controlling students' initial abilities.

Table 8. Parameter Estimates

\begin{tabular}{lcccc}
\hline Parameter & B & $\begin{array}{c}\text { Std. } \\
\text { Error }\end{array}$ & t & Sig. \\
\hline Intercept & 27,421 & 4,765 & 5.755 & 0.000 \\
{$[\mathrm{~B}=1.00]$} & 18,537 & 3,037 & 6.104 & 0.000 \\
\hline
\end{tabular}

Based on Table 8. t-test with $t=6.104$ and $p$-value $=$ $0.000<0.05$, also means that Ho is rejected. We can conclude that the mean ability to understand number concepts for students who are given local culture-based material is higher than students who are given material not based on local culture after controlling for initial abilities.

The results of the study provide an excellent picture of the ability to understand concepts for students who were taught with a local culture-based CM approach. That is to support the results of previous studies, the $\mathrm{CM}$ learning approach is effective for improving mathematical understanding [15][24]. It is a realistic mathematical approach by utilizing local contextual and cultural problems as its starting point. The ability to understand mathematical concepts for students who were taught with realistic mathematics learning approaches is higher than those who were taught with direct instruction when two groups of students are given material oriented to local culture (ethnomathematics) [25][26]. The same thing happened to improve mathematical problem solving [18] [12], also for mathematical communication [17], concept understanding [25]. Thus, we believe that the CM learning approach that is oriented towards local culture (ethnomathematics) has a positive effect on improving understanding of mathematics, especially the concept of numbers. Also, we believe that learning $\mathrm{CM}$ based on local culture (ethnomathematics) can improve mathematical abstraction abilities [27][28], improvement of cognitive level [29][30][31], mathematical representation [32] and problem-solving [33][34]. These are important mathematical abilities. 


\section{Conclusions}

This research concludes that there is a linear effect of the covariate (initial ability) on the ability of students to understand the concepts of learning in CM learning with a local cultural approach. Second, there is the influence of $\mathrm{CM}$ learning with the approach of local cultural approaches to the ability to understand number concepts. Furthermore, the mean ability to understand number concepts for students taught with higher CM learning than students taught with conventional learning than models after controlling students' initial abilities. Also, the mean ability to understand number concepts for students who were given local culture-based material was higher than students who were given material not based on local culture after controlling for initial abilities. Finally, we suggest mathematics education experts develop a model of local culture-based mathematics learning in the CM. It is a learning model that has a positive impact on mathematical ability.

\section{Acknowledgments}

We are very grateful to the leadership of the Faculty of Teacher Training and Education-Bengkulu University, the Al-Fida Bengkulu Foundation, and experts who have supported this research.

\section{REFERENCES}

[1] S. Suharto and W. Widada, "The Students' Anxiet y in Facing the Mathematical National Exams," Adv. Soc. Sci. Educ. Humanit. Res., vol. 253, no. Aes 2018, pp. 123-124, 2019.

[2] K. Gravemeijer, Developing Realistic Mathematics Education. Utrecht: Freudenthal Institute, 1994.

[3] G. Lappan et al., Getting to know Connected mathematics. New Jersey: Prentice Hall, 2002.

[4] Anonimous, "College of Natural Science Connected Mathematics Project," Michigan State University. https://connectedmath.msu.edu/the-math/math-goals-by-un it/. 2019.

[5] M. Rosa and D. C. Orey, "Ethnomathematics: the cultural aspects of mathematics," Rev. Latinoam. Etnomatemática, vol. 4, no. 2, pp. 32-54, 2011.

[6] D. Herawaty, W. Widada, T. Novita, L. Waroka, and A. N. M. T. Lubis, "Students' metacognition on mathematical problem solving through ethnomathematics in Rejang Lebong, Indonesia,” J. Phys. Conf. Ser., vol. 1088, 2018.

[7] D. Herawaty, W. Widada, K. Umam, Z. Nugroho, A. Falaq, and D. Anggoro, "The Improvement of the Understanding of Mathematical Concepts through the Implementation of Realistic Mathematics Learning and Ethnomathematics," Adv. Soc. Sci. Educ. Humanit. Res. Vol. 295, vol. 295, no.
ICETeP 2018, pp. 21-25, 2019.

[8] U. D'Ambrosio, "From Mathematics Education and Society to Mathematics Education and a Sustainable Civilization," Portland, Oregon, United States Proc. Eighth Int. Math. Educ. Soc. Conf., vol. 2, no. June, 2015.

[9] N. Syafriafdi, A. Fauzan, I. M. Arnawa, S. Anwar, and W. Widada, "The Tools of Mathematics Learning Based on Realistic Mathematics Education Approach in Elementary School to Improve Math Abilities," Univers. J. Educ. Res., vol. 7, no. 7, pp. 1532-1536, 2019.

[10] E. Phillips, "Connected Mathematics Project," Educ. Dev. Center, Inc., 2003.

[11] R. Eddy and T. Berry, "The Effects of Connected Mathematics Project 2 on Student Performance: Randomized Control Trial.” 2008.

[12] W. Widada, D. Herawaty, and A. N. M. T. Lubis, "Realistic mathematics learning based on the ethnomathematics in Bengkulu to improve students' cognitive level," J. Phys. Conf. Ser., vol. 1088, 2018.

[13] W. Widada, "Sintaks Model Pembelajaran Matematika Berdasarkan Perkembangan Kognitif Peserta Didik," J. Pendidik. Mat. Raflesia, vol. 1, no. 2, pp. 163-172, 2016.

[14] A. Kleinman, “The Role of Culture," Br. J. Psychiatry, vol. 151, pp. 447-454, 1987.

[15] IES, "WWC Intervention Report Connected Mathematics Project (CMP )," Prim. Math. Inst. Educ. Sci., no. February, pp. 1-26, 2017.

[16] J. S. Cain, "An Evaluation of the Connected Mathematics Project,” J. Educ. Res., vol. 95, no. 4, 2002.

[17] W. Widada, D. Herawaty, D. Yanti, and D. Izzawati, "The Student Mathematical Communication Ability in Learning Etnomathematics Orieted Realistic Mathematics," Int. J. Sci. Res., vol. 7, no. 9, pp. 881-884, 2018.

[18] W. Widada, D. Herawaty, A. Falaq, D. Anggoro, A. Yudha, and M. K. Hayati, "Ethnomathematics and Outdoor Learning to Improve Problem Solving Ability," Adv. Soc. Sci. Educ. Humanit. Res. Vol. 295, vol. 295, no. ICETeP 2018, pp. 13-16, 2019.

[19] K. François, "The Role of Ethnomathematics within Mathematics Education," Cent. Log. Philos. Sci. Free Univ. Brussels, no. December, pp. 1517-1526, 2010.

[20] C. Stathopoulou, P. Kotarinou, and P. Appelbaum, "Ethnomathematical research and drama in education techniques: developing a dialogue in a geometry class of 10th grade students," Rev. Latinoam. Etnomatemática, vol. 8, no. 2, pp. 105-135, 2015.

[21] R. A. Bishop, N. Iudians, and E. Partly, "Ethnomathematics and its Practice," vol. 2, pp. 23-25, 1994.

[22] W. Zhang and Q. Zhang, "Ethnomathematics and Its Integration within the Mathematics Curriculum," J. Math. Educ. (C) Educ. All, vol. 3, no. 1, pp. 151-157, 2010.

[23] W. Widada, Pendekatan Pembelajaran Matematika Berbasis Masalah. Surabaya: Unipa Press, 2004.

[24] W. Widada, "Proses Pencapaian Konsep Matematika 
dengan Memanfaatkan Media Pembelajaran Kontekstual," J. Penelit. Pendidik. Mat. dan Sains, vol. 22, no. 1, pp. 31-44, 2015.

[25] W. Widada, D. Herawaty, K. U. Z. Nugroho, and A. F. D. Anggoro, "The ability to Understanding of the Concept of Derivative Functions for Inter-Level Students During Ethnomathematics Learning," J. Phys. Conf. Ser., vol. 1179, no. 012056, pp. 1-6, 2019.

[26] W. Widada, D. Herawaty, S. Agriyanto, G. Octizasari, and S. G. Meri, "The improvement of trigonometry ability through connected mathematics learning models and scientific approaches the improvement of trigonometry ability through connected mathematics learning models and scientific approaches," J. Phys. Conf. Ser., vol. 1318, no. 012078 , pp. 1-6, 2019.

[27] D. O. Marika and D. Herawaty, "Pengembangan Bahan Ajar dengan Pendekatan Pembelajaran Santifik Berbantuan Geogebra Untuk Meningkatkan Kemampuan Spasial," J. Pendidik.

Mat. Raflesia, https//ejournal.unib.ac.id/index.php/jpmr, vol. 04, no. 02 , pp. 153-163, 2020.

[28] W. Widada, A. Agustina, S. Serlis, B. M. Dinata, and S. T. Hasari, "The abstraction ability of students in understanding the concept of geometry the abstraction ability of students in understanding the concept of geometry," J. Phys. Conf. Ser., vol. 1318, no. 012082, pp. $1-7,2019$.

[29] F. Aliza, W. Widada, and D. Herawaty, "Proses Kognitif Siswa dalam Memahami Matematika Berdasarkan Teori Perkembangan Skema Extended Level Triad ++ Selama Pembelajaran Berorientasi Etnomatematika," J. Pendidik. Mat. Raflesia, https//ejournal.unib.ac.id/index.php/jpmr, vol. 04 , no. 02 , pp. $145-152,2019$.

[30] F. Herdian et al., "Level Berpikir Siswa dalam Memahami Konsep dan Prinsip Bangun Ruang dengan Pendekatan Pembelajaran Etnomatematika Beradasarkan Teori APOS," J. Pendidik. Mat. Raflesia,https//ejournal.unib.ac.id/index.php/jpmr, vol. 04, no. 02, pp. 111-119, 2019.

[31] W. Widada, D. Herawaty, A. F. D. Anggoro, and K. U. Z. Nugroho, "The Trans Level Characteristics About Infinite Series," J U M A D I K A J. Magister Pendidik. Mat., vol. 1, no. 1, pp. 19-24, 2019.

[32] W. Widada, K. U. Z. Nugroho, W. P. Sari, and G. A. Pambudi, "The ability of mathematical representation through realistic mathematics learning based on ethnomathematics the ability of mathematical representation through realistic mathematics learning based on ethnomathematics," J. Phys. Conf. Ser., vol. 1318, no. 012073 , pp. 1-8, 2019.

[33] W. Widada, D. Herawaty, P. Mundana, Agustina, F. R. Putri, and A. F. D. Anggoro, "The REACT strategy and discovery learning to improve mathematical problem solving ability The REACT strategy and discovery learning to improve mathematical problem solving ability," J. Phys. Conf. Ser. Pap., vol. 1318, no. 012081, pp. 1-5, 2019.

[34] N. Ma'Rifah and W. Widada, "Pembelajaran TAI dengan Open Ended Problem untuk Meningkatkan Kemampuan Berpikir Kritis Mahasiswa Tadris Matematika IAIN
Curup,” J. Pendidik. Mat. Raflesia, vol. 4, no. 1, pp. 1-9, 2019. 